\title{
A Field Study for Assessing Risk-Contingent Credit for Kenyan Pastoralists and Dairy Farmers
}

\author{
Apurba Shee, Calum G. Turvey, Joshua Woodard
}

\begin{abstract}
Purpose - The purpose of this paper is to assess the feasibility of risk-contingent credit (RCC) by presenting an experimental and participatory game designed to explain the concept of RCC to Kenyan pastoralists and dairy farmers. The paper investigates the uptake potential of RCC through qualitative assessment of field experiments and focus groups.

Design/methodology/approach - The paper presents a method of community engagement through a participatory game played in a series of Focus Group Discussions (FGDs). The paper also presents theoretical justification of RCC in credit market structure.

Findings - The game effectively explains the concept and mechanism of RCC by reflecting local situation and production potential. Participatory exercises within focus group discussions indicate that there exists a strong interest and support for RCC.

Research limitations/ implications - The methodology described in this paper can be used in extension programs for promoting innovative rural microcredit in developing countries but should be modified according to the local production and associated weather and market risks.

Originality/value - Micro-insurance and credit program delivery can be improved by our innovative approach of community engagement for explaining financial products.

Keywords: Risk-contingent credit, Pastoral and dairy farmers, risk management, access to credit Paper type: Research paper
\end{abstract}

\section{Contact Author:}

Apurba Shee

International Food Policy Research Institute, a.shee@cgiar.org; shee.apurba@gmail.com

Apurba Shee is Associate Research Fellow, Environment and Production Technology Division, International Food Policy Research Institute, Washington DC, Calum G. Turvey is W.I. Myers Professor of Agricultural Finance, Charles H. Dyson School of Applied Economics and Management, Cornell University, Joshua Woodard is Assistant Professor, Charles H. Dyson School of Applied Economics and Management, Cornell University.

This research was supported by US Agency for International Development (USAID) BASIS Assets and Market Access (AMA) Research Program seed grant and W.I. Myers endowment funds, Cornell University. We would like to thank conference audiences at the Agricultural \& Applied Economics Association Annual Meeting (Minneapolis, 2014). We are grateful to Shibia Mohamed and Diba Galgallo for their excellent field support. We appreciate generous hospitality provided by the International Livestock Research Institute (Nairobi, Kenya). Finally, we thank all the participants in the focus groups and RCC game. 


\section{Introduction}

Agricultural risks and limited access to credit are not only serious impediments to agricultural productivity, but also remain two of the main sources of potential poverty traps in developing countries. With 75\% of Kenya’s population employed within agriculture, and 51\% of the country’s overall GDP derived from the sector, agricultural productivity is critical. Pastoral and dairy livestock production plays an important role in rural livelihoods in Kenya where the main risks in this sector are weather and market price variability. To a significant extent these uncertainties are attributable to credit constraints facing Kenyan farmers. Lack of credit constrains optimal input use, limits marketing opportunities, and contributes to disinvestment and poverty traps. While rural bank branches have grown $81 \%$ over the last five years, banks are still averse to lending in agriculture. Uninsured risks and lack of access to credit force farmers to adopt low-risk, low-return activities, resulting in wide-spread and persistent poverty.

One innovative credit mechanism that could not only enhance farmers’ access to credit but also help them manage risks is Risk Contingent Credit (RCC). RCC is a general term for any credit instrument that embeds within its structure a contingent claim or insurance which, when triggered transfers part or all of the borrower's liability to the lender or integrator/counterparty (Shee and Turvey 2012). Because RCC balances both financial risk and business risk it addresses many problems regarding credit in developing countries including (a) the relaxation of credit constraints, (b) mobilizing farmers' abilities to improve productivity and increase household income, (c) reducing credit risk, (d) maintaining liquidity balancing, (e) removal or reduction of collateral risk and risk rationing, and (f) reductions in loan default. When properly employed, risk-contingent credit structures can provide the proper incentives to entice banks to increase the supply of credit to small farmers. Even in regions that have access to credit, there is a significant number of farm 
households that 'risk-ration' themselves out of the credit market for fear of losing collateral and livelihoods when natural or economic adversity hits (for details about risk rationing see Boucher et al. 2008, Verteramo et al. 2015). As a target of rural credit policy, it is a pro-growth inclusive advancement on conventional credit products, and one we believe will ultimately impact credit demand and supply in a socially optimal way.

The objective of this study is to assess the uptake potential of RCC in pastoral and dairy farm communities in Kenya by using a participatory game played in a series of focus groups held by the authors in July 2013. This is done in the spirit of McPeak et al. (2010) who describe how 'games' were used to educate pastoralist in Kenya's indexed based livestock insurance scheme (see Chantarat et al. 2013). Thus, our approach is more qualitative than quantitative, but is a useful addition to the agricultural finance/risk/development literature by illustrating and describing how baseline information can be gathered in a pragmatic way. By engaging farmers in open discussion specific aspects of risk including source, seasonality, frequency, duration, intensity and consequences, can be established. These attributes can ultimately be part of the RCC design.

The next section discusses the evolution of risk-contingent credit. This is followed by an assessment of the productive investment potential and risks in pastoral and dairy farming in Kenya, followed by an overview of RCC and its theoretical justification in credit market structure. This is followed by a description of the participatory RCC game to effectively explain the concept and mechanism of RCC to farmers. The next section describes the findings of the field assessment from both pastoral and dairy farming areas. The final section provides concluding comments.

\section{The Evolution of Risk-Contingent Credit}

The idea of RCC first appeared in a description of programs in the Philippines, Sri Lanka and India 
in which farmers pledged a portion of any crop insurance indemnities to cover loan losses (Adams and Vogel 1986). This was based on an honor system with only an indirect linkage to credit. Jin and Turvey (2002) developed a number of RCC loan structures for operating loans, farm mortgages and bonds based on weather index insurance. Skees and Barnett (2006) introduced the idea of a meso-level insurance in which lenders acquired index insurance against perils that were highly correlated with loan losses. They describe a World Bank project in Malawi that linked index insurance to production loans and suggested that index insurance could also be linked to commercial loans. Other examples include insurance against El-nino related risks in Peru, the Indian MFI BASIX's purchase of rainfall insurance in 2004 and 2006 to offset loan losses against drought and flood perils; and the use of indexed based livestock insurance in Mongolia. Linkages to farmer producers under a meso-scheme are designed to make indemnity payments based on actual losses (Skees and Barnett 2006). The El-nino was followed up by Collier et al (2011) and Miranda and Gonzalez-Vega (2011), and Weber et al (2015) who discuss a meso-insurance scheme based on rainfall for cotton producers in Tajikistan. At the micro-level, Shee and Turvey (2012) showed how risk-contingent instruments can be priced in practice using simulated field data. They concluded that an imbedded price option for pulse crops in India provided downside risk protection for pulse farmers. Turvey, Bogan and Yu (2012) apply RCC to price risk protection for New York dairy farms, and Chantarat et al. $(2007,2008)$ adapt the model to pre-empt rainfall related famine risk in Kenya. Carter (2011) examined the impacts of linked credit on financial market deepening and its impacts on farm households, concluding that linked credit capitalized the adoption of new technology. In randomized control trials (RCT) Giné and Yang (2009) investigated adoption of an operating loan in Malawi in which the payoff was determined by rainfall, and Karlan et al. (2011) investigated the adoption of price-contingent credit in Ghana. 
The demand for RCC appears to be promising, but research is still in its infancy. For example in (unpublished) field research conducted by one of the authors in 2009 indicated that 57\% of Chinese farmers would be moderately interested or very interested in RCC type structures, and in 2010 this was 50\%. Likewise, in a 2011 survey of Mexican grain and oilseed farmers, identical questions indicated that $51 \%$ of participants would be interested in such a product. These are in line with the 17\% uptake rates found by Giné and Yang (2009) in Malawi. It should be noted however that Giné and Yang's (2009) RCT was tied to loans for the adoption of new technology and only 33\% of farmers offered conventional loans chose to accept it. A very important insight by Giné and Yang (2009) that requires much more study is the sensitivity of loan demand to the additional risk premium in interest rates. Using option pricing theory, Shee and Turvey (Table 3, Page 571 , 2012) show that the range of risk premiums relative to a $12 \%$ base ranged from $1.83 \%$ to $25.6 \%$ for different pulse crops in different Indian markets depending upon historical price volatility. Moreover, simulated results of representative farms for pulse crop farmers in India by Shee and Turvey (2012) indicate that risk contingent (price) credit can substantially improve minimum incomes, as well as lead to decreased risk in crop revenues, while increasing beneficial positive revenue skewness.

\section{Productive investments and risks in Kenya's pastoral and dairy economies}

Pastoralism is the key livelihood in the Arid and Semi-Arid Lands (ASAL) in northern Kenya. Pastoralists not only derive their diets from livestock such as milk, meat and blood (Fratkin and Roth, 2005) but they also consume market products (mainly cereals) by selling livestock (Barrett and Luseno, 2004). Figure 1 illustrates the main reasons that the households keep livestock in the region. The major importance of livestock is that they are the main source of savings and status, 
and also serve as a source of food from milk. Pastoralists also earn income from selling/trading milk, meat, and live animals.

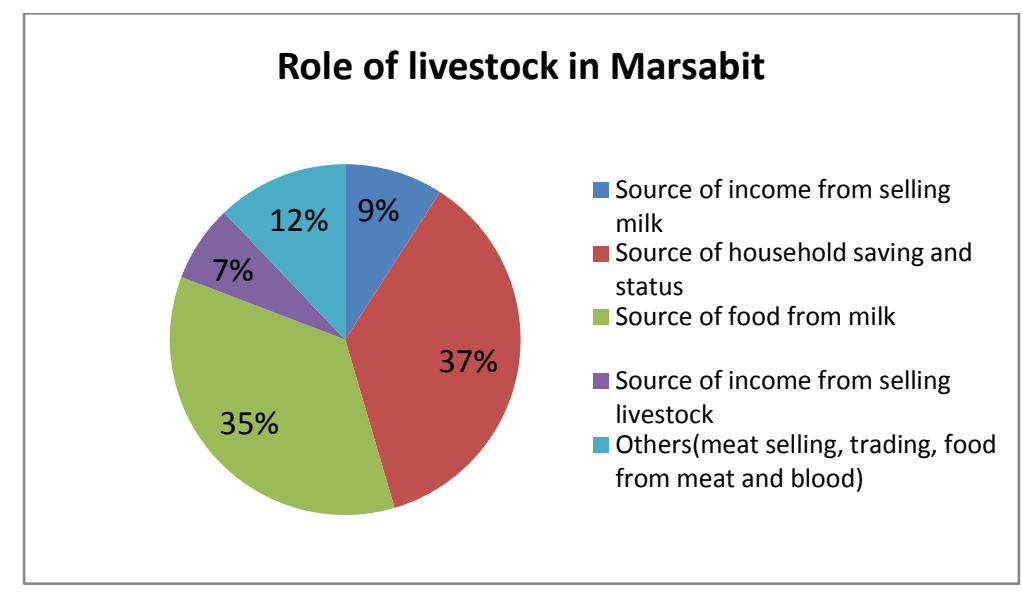

Figure 1 Role of livestock in Marsabit; Source: ILRI Household Survey

The primary investment vehicle is via expansion of herd size. Lybbert et al. (2004) argue that households with larger herd sizes have a greater potential to recover from extreme droughts, whereas those with smaller herds do not. Investment opportunities also exists for livestock trading, building of trading stocks, animal care, milk trade and selling, and small enterprises such as salt sales, fodder sales, and shop keeping. For agro-pastoralists, investment in rain-fed food crop production is also a productive investment opportunity in some areas.

The main uncertainty in the pastoral economy is weather (mainly drought). Other market and economic risks are also associated with drought conditions. During dry seasons, pastoralists face forage/feed scarcity, and as a result they migrate (and in extreme events they even destock). It is well documented that immediately following a drought, prices fall as herders cull their stocks and flood the market with meat. This is followed by a steep increase in prices as live animals clear from the market. Pastoralists are then left in a situation in which their herd stock is depleted, and 
restocking becomes prohibitively expensive. Given that livestock production is the main economic driver in this region, virtually all markets are affected by any economic shock as all potential livelihood activities are typically linked in some way with livestock markets.

Smallholder dairy farming plays a very important role in Kenya's economy, with more than one million smallholder dairy farmers contributing about 70 percent of gross milk production from farms (Muriuki 2011). Smallholder dairy farming is characterized by low productivity (about $5 \mathrm{~kg}$ milk per cow per day on average) and low input use. Mburu et al. (2007) identifies milk prices as one of the main risks in smallholder dairy farming and find that milk price negatively affects farmers' adoption of milk value chains. They also suggest that access to credit needs to be improved to help intensify production practices. The main investment needs in dairy farming are purchase of cows, feed and nutrient supplements, veterinary care, cattle sheds, and equipment such as pulverizes.

Variable seasonal weather conditions are the key source of risk in milk production in East Africa. In the dry season (for example Jan, Feb, March) farmers face feed scarcity, and as a result many farmers move their cattle. Due to this feed scarcity, milk supply falls, and as a result milk price increases. In wet seasons when more feed is available, milk production increases and abrupt ships in supply drive prices down significantly. Clearly there exists a dynamic relationship between weather condition and milk price, which is highly seasonal in nature, but the intensity can vary from year-to-year (Figure 2). Not only is it important to investigate the weather and price risk in detail, but it is critical to develop an appropriate pricing formula for managing risk for dairy farmers. 


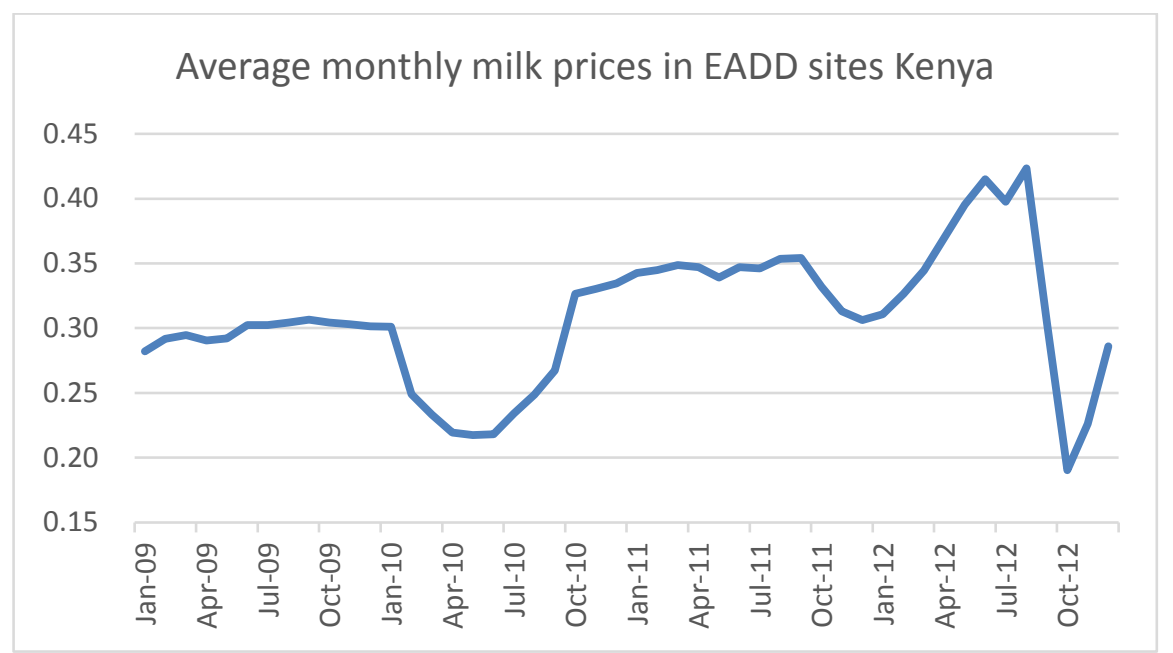

Figure 2 Kenya milk prices in \$/lbs; Source International Livestock Research Institute; displays monthly price series for milk received by dairy farmers from January 2009 to December 2012. The graph reveals significant periods in which prices drop precipitously or rise rapidly. These movements are largely weather related, and are linked to the arrival, duration and intensity of long and short rains, and as such are largely driven by supply shocks, although perhaps not exclusively.

\section{Overview of risk contingent credit}

The risks faced by Kenyan pastoralist and dairy farmer significantly impact their willingness to use credit, and perhaps more significantly their ability to source formal credit given the significant business risks involved which could ultimately lead to collateral loss. 


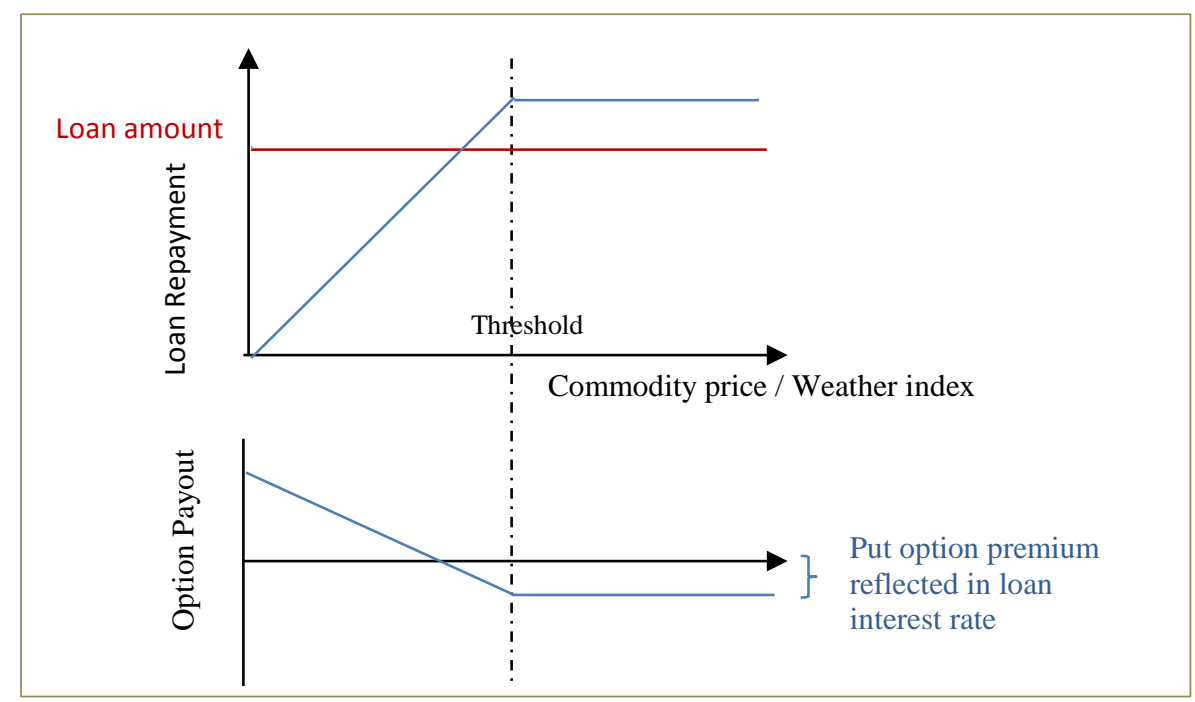

Figure 3 Schematic of risk-contingent credit

The RCC mechanism is depicted in figure 1 where the upper graph shows loan repayment and lower graph represents underlying option (insurance) payout. If the underlying risk (weather and/or commodity price-related) increases and crosses a certain threshold, the total repayment obligation of a farmer falls linearly. On the other hand, if the underlying risk decreases beyond the threshold, the loan has to be repaid with the additional risk-contingent interest rate load (which includes a risk premium above the base market rate). Risk contingent credit has therefore the unique characteristic that even though farmers have to pay a premium (in the form of higher interest) during normal circumstances, they are able to insure default risk. RCC is priced to an actuarially fair interest rate that is interlinked with the underlying risk. RCC thus offers a market-based solution that would provide larger and long term credit to cater to the investment needs in agriculture. The advantages of risk contingent-credit can be summarized as follows:

1) A common argument for the stagnant agricultural development in sub-Saharan Africa is that the absence of credit leads to inefficient use of inputs, suboptimal production, lower food supply, and higher priced food products. Improved access to credit and downside risk 
management through RCC can alleviate many of these constraints in the short run and encourage technology adoption and growth in the long term.

2) Since RCC embeds an insurance component that mitigates risks in agriculture, supporting production at times of negative shocks, it can promote resilience among farmers.

3) With the insurance component embedded in the credit product, lenders will reduce (or eliminate) collateral requirements, thus increasing demand by poor and risk-rationed smallholder farmers. It also eliminates the drawbacks of standalone index insurance products by not requiring the farmers who may be liquidity constrained to pay upfront premium.

4) Because the credit is interlinked with the price and/or quantity risks of the product produced by the farmer, loan default risk can be reduced significantly.

The approach to designing an RCC product involves the calculation of actuarial options/insurance premiums included directly into the credit formulas for risk-contingent loans. The risk-adjusted interest rates can be determined above the base interest rate of a collateralized loan that reflects the expected value of the indemnified risk. Following Shee and Turvey (2012), we assume that the lender is indifferent between receiving the present value of an operating loan $f$, at market interest rate $r^{* *}$ and a risk-contingent operating loan with an embedded option at an interest rate $r^{*}$. The interest rate, therefore, is the rate that would make the lender indifferent between an operating loan with the linked weather option and one without the option. Assuming a hedge ratio $\psi$, strike price $K_{W}$ and loan length $\mathrm{T}$, the interest rate is determined by

$$
r^{*}=\frac{\ln \left[\frac{\psi E\left[\operatorname{Max}\left(0, K_{W}-W(t)\right)\right]}{f}+e^{\left(r^{* *}\right) T}\right]}{T} \text {, with } r^{*}>r^{* *}>r \text { and, } \psi=\frac{f}{K_{W}}
$$


Weather-related information, such as rainfall and vegetation, can be used to measure weather risks faced by farmers. The term $E\left[\operatorname{Max}\left(0, K_{W}-W(t)\right)\right]$ in (1) captures the indemnity structure and can be tied to a weather index insurance such as in Jin and Turvey (2002) and Giné and Yang (2009) , the equilibrium option price of a non-traded cash commodity such as in Shee and Turvey (2012) or a traded option such as in Turvey et al (2012). Although these papers have examined RCC at the micro-level, a similar structure can be used for meso-insurance as well, with the term $\psi$ adjusted to capture aggregated loan portfolios.

RCC structures have several desirable features. Unlike traditional credit products, RCC structures facilitate risk management by layering hedging protection into loan repayment obligations. Due to the nature of the agricultural and financial infrastructure in developing countries, producers are typically unable to access or replicate these types of risk management tools themselves. On the other hand, financial institutions are in a much more natural position to provide contingencies for and bear such risks. Specifically, the lender is in a natural position to aggregate and manage these risks (with insurance and reinsurance partners) for pools of producers and can also more easily access global financial and reinsurance markets to hedge the resulting risk in their portfolios arising from the RCC contracts. Finally, packaging the loan directly with the risk management instrument reduces due diligence and agency costs associated with verifying if the farmer is insured or not, and in fact any "indemnity" type payments never need pass through the farmers' hand, thus resulting in reduced credit risk for the bank. 


\section{Description of field games for RCC}

In this section we describe the field games. The games were used as a vehicle for a broader discussion of livelihoods, risk and credit. The study regions were in the temperate dairy region around Olkalou in Nyandarua County, and arid and semi-arid pastoral region in Northern Kenyan Marsabit County. Both regions are of interest because both are affected by the long and short rains that are characteristic of Sub-Saharan Africa. Pastoral farmers face drought risk when either long or short, or both long and short rains fail. Participants noted that in the dairy regions of southern Kenya, there is a strong relationship between seasonal rainfall patterns and milk prices. We discuss the precise locations and agricultural conditions in the summary section that follows.

As previously indicated, little is known about how farmers would perceive RCC. Our context is the linking of RCC to a weather index insurance with basis risk. Of concern is farmers' financial understanding of how RCC pays indemnities (McCPeak et al 2009) and relates to loan repayment, sensitivities to the interest rate premiums as found in Giné and Yang (2009), and potential Type I and Type II errors arising from spatial basis risk. The purpose of designing a game for RCC is to convey the attributes and features of RCC using a participatory role play. The objective was to demonstrate how RCC works and how it is able to provide protection against specific covariate risks. The game was played in three parts and moderated by staff from the International Livestock Research Institute (ILRI, Nairobi Kenya) who were familiar with local agricultural conditions and practices and could speak local dialects. The authors were in attendance at all focus groups and meetings and were available for questioning and discussion. Our focus groups included dairy farmers in a temperate agricultural region and pastoral herders and farmers in arid and semi-arid regions. 
Play 1: After dividing the participants into 7-8 dyadic groups, play 1 information sheet (see appendix) is distributed with a verbal explanation in local dialect. The participants were provided with two choices; traditional practice $(\mathrm{T})$ and high potential practice $(\mathrm{H})$. Traditional practice (traditional dairy practice, traditional agriculture etc.) does not need a loan because it requires less investment. Using traditional practice a farmer can earn 10,000 ksh (Kenyan shilling) in a normal season and earn nothing (livestock die or crop fails) in bad season. High potential practice, on the other hand requires a loan (traditional credit or TC) of 4,000 ksh for investment in a high quality dairy practice or improved crop production practice. High potential practice can yield earnings of $30,000 \mathrm{ksh}$ in a good season and zero earning in bad season.

After understanding these two options, the responses from farmer groups were recorded on a flip chart. A realized weather (risk) condition was then decided through a random draw of a marker out of a bag with 1 red (represents bad weather) and 4 green (represents normal weather) markers. The end of season earnings for all the groups were then calculated (see appendix table A1). The groups that selected traditional practice with no credit earned 10,000 ksh in a normal season but earn nothing in a bad season. The groups that chose the high potential practice with traditional credit earned 26,000 ksh $(30,000-4,000)$ in a normal season but in bad season their earning was $-4,000$ ksh because of loan repayments.

Play 2: In play 2, RCC was introduced with high potential practice (H) as a third option. With RCC, if the season was normal farmers had to repay the principal amount (4,000 ksh) with a risk premium of $400 \mathrm{ksh}$ (this amount is actuarially fair interest rate with RCC and loading from the bank). On the other hand, if the realized season was bad, with RCC the farmers were not required to repay any part of the loan (principal or interest). Hence, in play 2, participants could choose from three choice sets as discussed in the play 2 information sheet (see appendix). After deciding 
the realized season through a random draw as mentioned in play 1, the end of season earning was calculated using the following formula.

\section{End of the season earning = amount earned from the practice - loan repayment - risk premium}

With the RCC and the high potential practice, the respondents end of the season earning was 25,600 ksh $(30,000$ - 4,000 - 400) with a normal season but seasonal earnings from a bad season was zero because there was no repayment obligation with RCC in the bad season (see appendix table A1). Examining the earning table for all three options, it was observed that with RCC farmers were not subject to negative seasonal earnings but with traditional credit they earned negative $4000 \mathrm{ksh}$ in the bad season, even though normal season earning with RCC was less than tradition credit. It is through this mechanism that RCC protects downside risks faced by farmers; even though farmers are worse off during the normal season compared to tradition credit, they are able to get protection in the bad season (protection against downside risks).

Play 3: In play 3, we introduced the concept and behavior of RCC under basis risk. Basis risk is a situation when individual risk experience does not match with what aggregate index predicts. This is inherent problem with any index based insurance (Barnett 2004; Norton et al. 2013; Woodard and Garcia 2008a, b). Due to basis risk there might be a small chance that the actual conditions faced by the farmer may be bad, but the contingent situation could be normal requiring that farmers have to repay the loan with contingent interest rates. This play has an extra stage where basis risk is determined by a random draw of color markers similar to the determination of realized seasons. Drawing a green marker meant that contingent credit operated as described earlier (repay principal amount with risk premium in normal season, but in bad season repay nothing). But if the draw is a red marker, farmers were required to pay the full principal amount (4000 ksh) with a risk 
premium (400 ksh). The sample of calculated end-of-season earnings with basis risk are provided in appendix table A1 using the same formula given in play 2.

\section{Findings of the field assessment and focus groups}

In this section we present qualitative results from a series of focus groups in two contrasting livestock producing regions in Kenya. At each of the four focus group sites (see Figure 4) we conducted an RCC game as described in last section. The local experts introduced the RCC game, indicating that we were to discuss the risk and credit situation in their livelihood, explaining that we were there to understand risk and credit, that nothing was to be sold or given, and that we were there to gain insights for research and potential product development purposes. The purpose of the RCC game in the focus groups were not to gather primary data for empirical analysis, but rather to generated group discussion, identify high level information regarding risks faced and potential product feasibility, and to gauge overall interest in RCC. We document the responses in the focus groups along with RCC games and report the nature of the discussions as they unfolded. Focus groups were guided on the basis of the following; understanding farmers' livelihood, risks and coping mechanism, credit demand, and perception about RCC. 


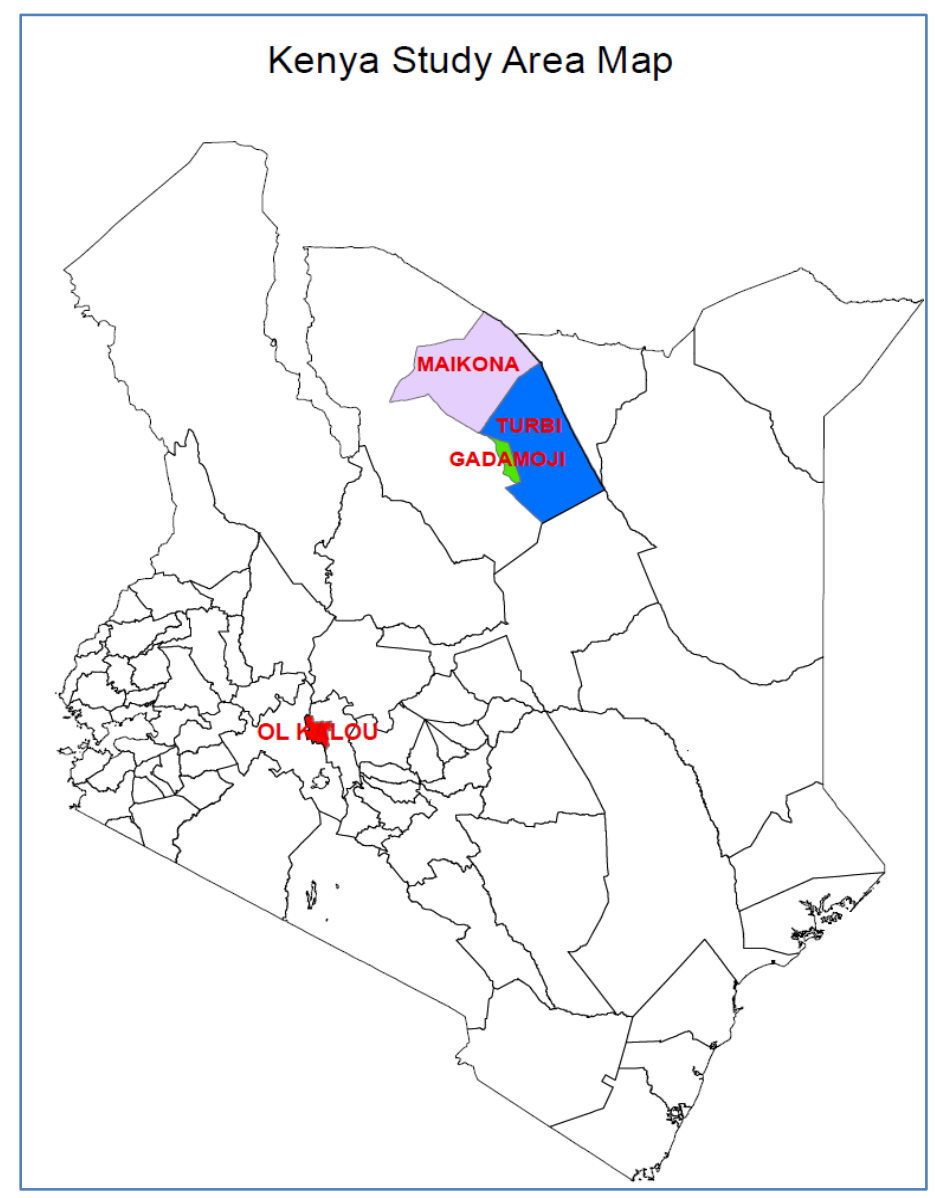

Figure 4 RCC study sites in Kenya

\section{Olkalou sub-county}

Olkalou sub-county is located in a remote pasture land in Nayandarua County where the East African Dairy Development (EADD) project, a milk value chain initiative lead by Heifer International, helps local farmers centrally deliver milk for processing. 23 small dairy producers, including 5 women, participated in the focus group discussion. The participants were members of a dairy producers' organizations of dairy hubs in the area promoted by EADD. Average dairy cow holding per producer household reported was about three to five. The necessary inputs for dairy farming as mentioned in the discussion were feed, nutrient supplements, cattle sheds, veterinary care, wiring and fencing for paddocks, among others. Fodder is usually grown on the farm, and 
some farmers lease lands for fodder production. They also purchase feed from input shops and other suppliers. Artificial insemination services are also used with support EADD. Some dairy farmers are also involved in mixed farming including maize, beans, and poultry.

Seasonal production fluctuations and milk price volatility were reported as the primary sources of risk in dairy production. Milk prices fluctuate widely according to rainy/dry seasons. In the dry season (for example Jan, Feb, March) the price range is about 30-34 ksh/liter but forage, feeds and supplements must be purchased at a higher price. However, in the wet season when forage and grazing is abundant, market prices typically fall to about $22-24 \mathrm{ksh} / \mathrm{liter}$. The seasonality of prices and the volatility of prices within the seasons were universally acknowledged by the producers.

Farmers’ demand for credit was greatest for animal purchases. A typical farmer required about 40,000 ksh to purchase a cow, but some farmers were willing to borrow between 100,000 to as high as 200,000 ksh if they could obtain the credit. Loans in some cases were available from the Agricultural Development Cooperation as well as commercial sources such as Equity Bank. Some farmers were members of a self-help saving and lending groups. This was referred to as a 'village Bank'. Farmers agreed generally that the repayment period and timing of credit did not often match the production cycle or the rainfall cycle. With animals required for collateral, farmers were risk rationed and unwilling to expand credit for fear of losing the animals, and hence their basic livelihood. Likewise it was acknowledged that lenders were unwilling to lend large expansionary type loans to meet demand in any case. 
When the RCC game was played with risk contingent credit linked to the price of milk, farmers were able to immediately see how it would balance the risks that they face. In play 2, all 7 groups chose high potential practice with RCC rather than traditional credit option. Several forms of RCC were discussed. The most obvious form was to link the price of milk to the loan, but which price to use? The dynamics of prices in the wet season are substantially different from those in the dry season including underlying volatility. This suggests that an RCC product might be best employed on dual price triggers, one for the wet season price and the other for the dry season. Variants on this include designing a product on the average price within each season. Farmers also discussed the counter-cyclicality of milk prices and feed costs for which a gross margin product might be effective. An advantage of a gross margin product is that it would be smoother, or less volatile, than prices alone and could be assigned to the average gross margin across seasons. Indeed, similar approaches have become the preferred risk management policy vehicle in the United States (Woodard and Baker, 2013).

\section{Turbi sub-county}

Pastoral production systems in Northern Kenya are in stark contrast to the temperate dairy region discussed above. Pastoral livestock grazing is the main livelihood in the region, as crop production is largely not feasible due to low and erratic rainfall and poor soil conditions. Turbi is a remote pastoral sub-county in Marsabit County in Northern Kenya. 16 pastoral farmers including 10 women participated in the focus group discussion. The main livestock reported were camel and goat (very few pastoralists raise cattle) in Turbi. Turbi is located close to the Ethiopian border, and 
skirmishes with neighboring villages regarding grazing rights are not entirely uncommon. A typical household would have about 5 camels and 30-40 goats on average. The main livestock market was located in Moyale, a town bordering with Ethiopia. As reported in the focus group, the price of an adult camel ranged from 25,000 ksh to 40,000 ksh whereas price of a goat ranged from 4,000 ksh to 8,000 ksh. All women participants were from women self-help groups. The self-help group members do various enterprising activities such as livestock trading, maize milling, and milk selling etc. There were at least 5 different women's groups in the village. There was no local bank or bank branch, but the self-help groups have opened bank accounts in distant Marsabit to facilitate group lending activities.

Drought related livestock death and livestock price variability are reported as major risks along with disease, predation, and banditry. Farmers noted that even when farmers did not face loss of herd, drought had a residual effect on livestock market prices. In drought situations, most pastoralists destock. A further example of the nature of the systemic and covariate risks is that most of the small businesses and self-help group activities were positively correlated with the livestock cycle. Livestock mortality due to drought or related market forces also impact these entrepreneurial activities. Price of a cattle in normal season was about 27,000 ksh, but villagers also noted that the price could be as low as 8,000 ksh. From a consensus estimate by the group, the livestock mortality rate would be about $80 \%$ for cattle, $20 \%$ for camel, and about $50-80 \%$ for goats in extreme drought condition.

Reports of risk rationing were widespread. Pastoralists were explicit in their views that taking a loan would jeopardize their asset base, and they were afraid of losing collateral. In other words, even though there was a demand for credit, they rationed themselves out of the credit market. For example, Equity Bank provides loans but most do not borrow because of fear of 
collateral loss. Borrowing and lending from friends and relatives on a reciprocal basis was a common means to avoid collateral loss on formal loans. When asked how much they would borrow without collateral requirement, they mentioned a need of 100,000 - 300,000 ksh for various entrepreneurial activities such as milk and meat trade, small shop, animal tracking etc.

When playing the RCC game, six groups were formed. All 6 groups indicated that they would favor high potential practice with the credit option. In play 2, 5 of the 6 groups opted for high production using RCC rather than traditional credit. They were willing to pay a premium for risk protection against drought events. An interesting note is the systematic, covariate, relationship across enterprises. In these local communities the entirety of the economy is "co-dependent" in covariate shocks such as drought. This suggests that even households with no herds, but run some other business that is economically dependent upon herds, can also benefit from RCC.

\section{Maikona sub-county}

The next focus group was held in a village called Kalacha located in Maikona sub-county in Marsabit. Its terrain is flat and stony over large sections with intermittent areas of sandy loam. Livestock are predominantly camel, goats and sheep. At this focus group 17 pastoralists including 8 women participated. This village too has self-help groups that provided soft loans to members. Loans were made for entrepreneurial activities such as salt sales, hand crafts such as mats, fodder sales, hides and skin trading, timber sale, shop keeping, and the sale of camel milk. Camel cows are the most valuable not only in price, but also to the community, so much so that the sale of one (even though privately owned) must be negotiated with village leaders. They are assumed to be community property even with individual ownership. The reasoning is that the pastoral community needs a fixed number of camel cows to be sustainable, and so the sale of one or more might affect the critical mass. Bull camels, however can be sold at the owner's will. From a consensus estimate 
by focus group members, on average each household owned about 10 camels, 30 goats and 50 sheep. There were no cattle in this area. Camel prices depend upon body condition and ranged from 53,000 ksh (highest ever), but in bad times this could be as low as 20,000 ksh. The price ranges for goat and sheep were 3,000- 6,000 ksh and 1,500-3,000 ksh. As reported by the participants, drought related livestock loss is the main risk and in extreme drought conditions the mortality rates for camel, goat and sheep would be about $30 \%, 80 \%$, and $50 \%$, respectively. ${ }^{1}$

Although loans are available from Equity Bank in Marsabit, for pastoralists it is difficult to obtain a loan because of collateral risk. Similar to the producers in Turbi, this group was extremely risk rationed. However an NGO has deposited security in a local bank to offset risk so that herders were able to borrow up to 100,000 - 200,000 ksh, but required savings and collateral in any case. In most cases these requirements appeared to be prohibitive, sometimes resulting in deposit collateral requirements that were nearly the size of the proposed loan.

The RCC game generated interesting discussions. Some discussants mentioned that reduced livestock supply in drought situations may increase prices if farmers could maintain livestock numbers without mass culling making loan repayment easier. It should be noted that the signal of risk rationing was not as strong in this group, and this may be due to SHG lending in the village with lower interest rates $(10 \%)$ and more flexible terms. This group also seems to be constrained by solvency and liquidity issues. In play 2, all groups selected high potential practice

\footnotetext{
${ }^{1}$ There is a very interesting communal support and informal risk sharing mechanism in the area in time of drought. Herders who did not lose camel cows would make a loan of (one or more) camel cows to another herder who lost animals. This is a usufruct type of loan. The borrower cannot sell the animal and any dealings with female offspring need to be approved by the owner. The borrower however, can sell bull offspring at will. The idea is of reciprocity since the next disaster may impact the lender and not the borrower, and in this case the original borrower will return the camel cow or calf to the original lender. This type of "usufruct loan" only applies to camels and not cattle, goats or sheep. The same was noted in Turbi and generally holds throughout the Marsabit County.
} 
with RCC. They understood that a premium was involved and it would be more costly in good seasons. But they also recognized that this paid for the protection of loan in the bad season.

\section{Gadamoji sub-county}

Sagente is a rural village with agro-pastoral setup located in Gadamoji sub-county in Marsabit. The focus group included 21 farmers of which 6 were women. The men were herders, also involved in mixed farming with crops mainly maize and beans. The women were part of three self-help groups. Key livestock raised were goats, cattle and chicken with average herd size being 10, 2 and 5, respectively. Average prices ranged between 3,000-6,000 ksh, 15,000 - 25,000 ksh, 300-500 ksh, for goat, cattle and chicken, respectively. No camels and sheep were reported by the group. Other activities included sales of milk, eggs, and other small businesses. A typical configuration for crop cultivation was one acre of beans for 3 acres of maize. Maize and beans are mostly consumed at home, but some was sold in the Marsabit market.

The major risk faced by the farmers is drought. Pests and disease also affect revenues. Prices are also variable but it seems this was not a major concern. In terms of drought, farmers discussed the failure of long and short rains. They indicated that if the short rains failed they could survive with adequate food. This is largely due to a community response of 'neighbors helping neighbors' and other reciprocal based interventions between families and friends. When long rains failed things became very difficult with major disruption to household and local economies. However when both long and short rains failed, wide spread famine resulted. Indeed, in 2013 when these focus groups were held, the agricultural economy still had not recovered from failure of long and short rains in 2010. Nonetheless when discussion was opened on whether drought risk or price risk would be best for farmers in this region one farmer pointedly remarked that price risk protection is of no use when crops have burned in the field and livestock were dead. Cattle loss 
was about $80 \%$ with the $2010 / 2011$ (failure of short and long rains) famine. As reported by the group, average farmer would lose $80 \%$ cattle and $30 \%$ goat in case of extreme drought.

Credit is accessed through the Kenya Women Finance Trust (KWFT), Equity Bank, and SHG loaning and savings. KWFT has made one year agricultural loans for vegetable production, livestock raising and trading with fixed repayment schedule. The interest rate for the self-help group loan was about $20 \%$. Equity bank would loan up to 100,000 ksh with $18 \%$ interest rate but only for 6 months. All borrowings required savings as collateral for borrowing. For a variety of reasons, risk rationing does not seem to be an issue with this group, perhaps because of community intervention in times of drought. Respondents indicated that if they could obtain a loan with minimal conditions they would happily borrow more money. But again, the fixed repayment scheme is a barrier. If loans can be flexible to match the timing and sequencing of cash flow from agricultural production they would borrow more.

When playing the RCC game play 1, 6 groups chose high potential production with traditional credit while 2 groups chose production with no loan and no loss. But in play 2 when offered RCC all groups opted for high potential practice with RCC. They indicated that with the structure of RCC they could expand their herd. Also, with crop production limited by access to fertilizer and pesticides, crop farmers considered how they could use RCC to purchase these basic inputs. Participants indicated that they would use RCC for a variety of purposes including herd expansion, start or expand livestock trading, pay school fees, start businesses, expand crop cultivation, or purchase better breed of cattle for milk production.

\section{Conclusions}


Risk-contingent credit is an insurance embedded credit product designed to manage weather and market risks, and to improve access to credit for smallholder farmers. From a financial development perspective, RCC is an important innovation that has potential to encourage agricultural technology adoption and build resilience which can ultimately contribute to agricultural development in sub-Saharan Africa. Through a series of focus groups with dairy and pastoral farmers in Kenya, and a "game” to explain how RCC operates, there appears to be strong interest, support, and need for RCC type structures. This appears to be universal in the areas we visited. Farmers certainly understood the concept and mechanism for RCC and could imagine how it would benefit them. Following our focus groups and games, we received numerous messages from the participating farmers asking when RCC would be available in the respective areas.

The methodology described in this paper can be used in extension programs for promoting innovative rural microcredit in developing countries, but should be modified according to the local production and associated risks farmers face. It is important to point out that RCC can take many forms, and its implementation ought to consider the specific needs of farmers. With Kenyan dairy farmers the risk is actually in operating margins across rainfall-contingent price dynamics. RCC could be linked directly to prices, price-feed margins, or directly to dry and wet seasonal activities. Which is most correlated with farm risks is an empirical question. For northern Kenyan pastoralists, RCC using drought related livestock mortality index can be developed, but alternative mechanisms should also be considered including duration or failure of long and/or short rains with scaled tranches based on the intensity or duration of the drought. Given the importance of good product structure on uptake, future research is needed on developing suitable RCC designs for both dairy and pastoral livestock farmers to promote RCC pilots in the area. 


\section{References}

Adams, D.W. and R.C. Vogel (1986) "Rural Financial Markets in Low-income Countries: Recent Controversies and Lessons”, World Development, 14(4):477-487.

Barnett, B.J. (2004). Agricultural index insurance products: strengths and limitations. Agricultural Outlook Forum, downloaded from http://ageconsearch.umn.edu/handle/32971.

Barrett, C.B. and Luseno, W. (2004). "Decomposing producer price risk: a policy analysis tool with an application to northern Kenyan livestock market”, Food Policy 29: 293-405.

Boucher, S. R., Carter, M. R., and Guirkinger, C. (2008). "Risk Rationing and Wealth Effects in Credit Markets: Theory and Implication for Agricultural Development”, American Journal of Agricultural Economics, 90(2),409-423

Carter, M.R., 2011. "The Impact of Interlinked Index Insurance and Credit Contracts on Financial Market Deepening and Small Farm Productivity”, Selected Paper. Annual Meeting of the American Applied Economics Association, Pittsburgh PA, July 24-26.

Chantarat, S., C.G. Turvey, A.E. Mode and C. B. Barrett (2008) "Improving Humanitarian Response to Slow-onset Disasters Using Famine-Indexed Weather Derivatives”, Agricultural Finance Review 68(1);169 - 195.

Chantarat, S., A. G., Mude, C.B. Barrett, and M.R. Carter, (2013). "Designing index-based livestock insurance for managing asset risk in northern Kenya", Journal of Risk and Insurance, 80(1), 205-237.

Collier,B. A. L. Katchova, J. R. Skees (2011). "Loan portfolio performance and El Niño, an Intervention Analysis", Agricultural Finance Review, 71(1):98 - 119.

Fratkin, E. and Roth, E. (2005). As pastoralists settle: social, health and economic consequences of pastoral sedentarization in Marsabit district, Kenya. Kluwer Academic Publishers, New York.

Giné, X. and D. Yang (2009). "Insurance, Credit, and Technology Adoption: Field Experimental Evidence from Malawi” Journal of Development Economics, 89 (2009) 1-11.

Jin, Y., And C.G Turvey (2002). "Hedging Financial and Business Risks in Agriculture with Commodity-Linked Loans”, Agricultural Finance Review, 62(1), 41-57.

Karlan, D., E. Kutsoati, M. McMillan and C. Udry (2011). "Crop Price Indemnified Loans for Farmers: a Pilot Experiment in Rural Ghana.” The Journal of Risk and Insurance, 2011, Vol. 78, No. 1, 37-55. 
Lybbert, T., Barrett, C.,Desta, S. and Coppock, D. (2004). "Stochastic wealth dynamics and risk management among a poor population”, Economic Journal, 114:750-777.

Mburu, L. M., Wakhungu, J. W., and Gitu, K.W. (2007). "Determinants of smallholder dairy farmers' adoption of various milk marketing channels in Kenya highlands”, Livestock Research for Rural Development, 19 (9).

McPeak, J., Chantarat, S., \& Mude, A. (2010). "Explaining index-based livestock insurance to pastoralists”, Agricultural Finance Review, 70(3), 333-352.

Miranda, M.J. and C. Gonzalez-Vega (2011). “Systemic Risk, Index Insurance, and Optimal Management of Agricultural Loan Portfolios in Developing Countries” American Journal of Agricultural Economics, 93(2): 399-406.

Muriuki, H. G. (2011). Dairy development in Kenya. FAO, Rome.

Norton, M.T, C. G. Turvey and D. Osgood (2013) "Quantifying Spatial Basis Risk for Weather Index Insurance.” Journal of Risk Finance, 14(1):20 - 34.

Shee, A. and Turvey, C. G. (2012). "Collateral-Free Lending with Risk-Contingent Credit for Agricultural Development: Indemnifying Loans against Pulse Crop Price Risk in India.” Agricultural Economics, 43: 561-574.

Skees J.R. and B. J. Barnett, (2006),"Enhancing microfinance using index-based risk-transfer products", Agricultural Finance Review, 66(2): 235 - 250

Turvey, C. G. (2006). "Managing food industry business and financial risks with commoditylinked credit instruments.” Agribusiness: An International Journal, Vol. 22(4) 523-545.

Turvey, C.G. (2008) "The pricing, structure, and function of weather-linked bonds, mortgages, and operating credit." Agricultural Finance Review, 68(1):135 - 150.

Turvey, C. G., V.L. Bogan and C. Yu (2012) "Small Business and Risk Contingent Credit.” Journal of Risk Finance, 13(5):491 - 506.

Verteramo-Chiu, L. J., S. V. Khantacharana, and C. G. Turvey (2014) "Risk Rationing and the Demand for Agricultural Credit: A Comparative Investigation of Mexico and China.” Agricultural Finance Review, 74(2):248 - 270

Weber R., W. Fecke ， I. Moeller , O. Musshoff , (2015) "Meso-level weather index insurance: Overcoming low risk reduction potential of micro-level approaches", Agricultural Finance Review, 75(1):31-46 
Woodard, J.D. and D. Baker, "2013 Farm Bill Dairy Title Proposals Redistribute Program Benefits toward States with Larger Farms", Choices 28(3):1-5

Woodard, J. D. and P. Garcia (2008a) "Basis Risk and Weather Hedging Effectiveness." Agricultural Finance Review, 68(1):99 - 118.

Woodard, J. D. and P. Garcia (2008b) "Weather Derivatives, Spatial Aggregation, and Systemic Risk: Implications for Reinsurance Hedging.” Journal of Agricultural and Resource Economics, 33(1):34 - 51 . 


\section{Appendix}

\section{Play 1 information sheet}

(1) Make your decisions

\begin{tabular}{l} 
Traditional Practice $(\mathrm{T})$ \\
Normal season: earn $=10,000$ \\
Bad season: earn $=0$ \\
No Credit Needed $(\mathrm{N})$ \\
Pay: 0 \\
\hline
\end{tabular}
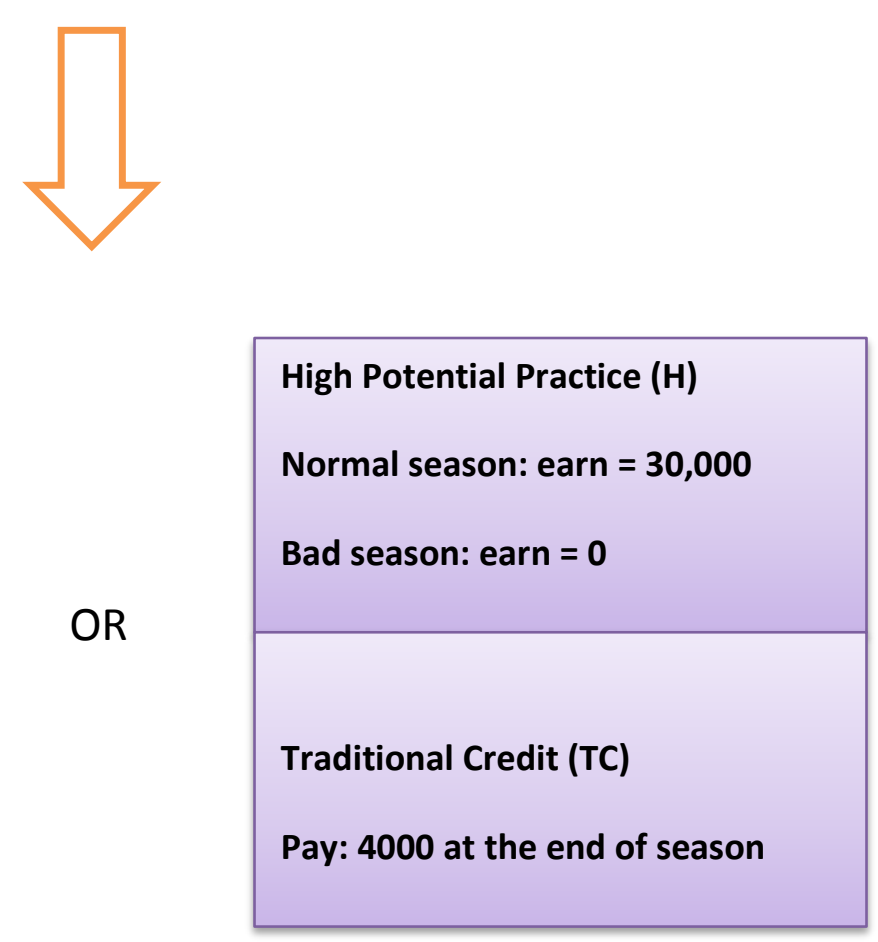

(2) Good season and bad season determined through random draw

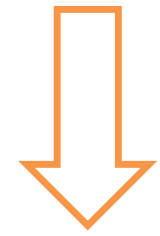

(3) End of season earning = Amount earn - Loan repayment 


\section{Play 2 information sheet}

(1) Make your decisions

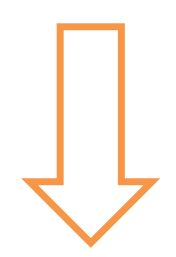

\begin{tabular}{l} 
Traditional Practice $(\mathrm{T})$ \\
Normal season: earn $=10,000$ \\
Bad season: earn $=0$ \\
No Credit Needed $(\mathrm{N})$ \\
Pay: 0 \\
\hline
\end{tabular}

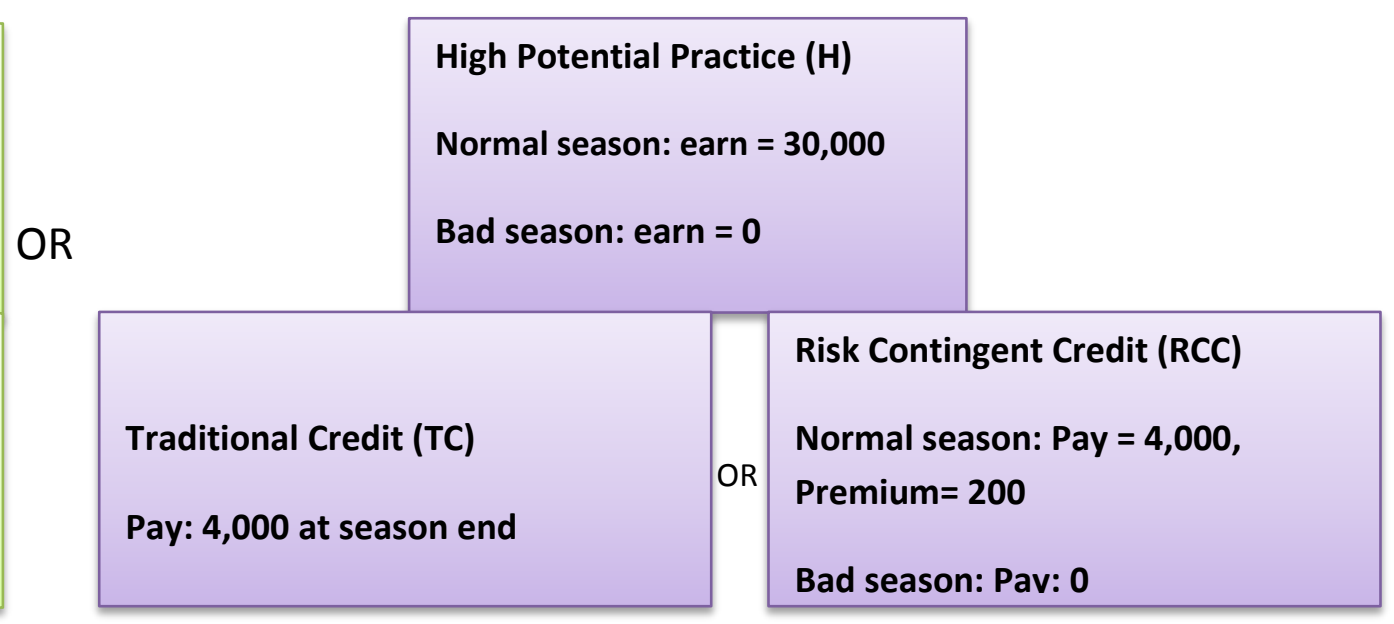

(2) Good season and bad season determined through random draw

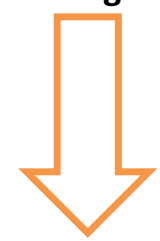

(3) End of season earning = Amount earn - Loan repayment - Premium 


\section{Play 3 information sheet}

(1) Make your decisions

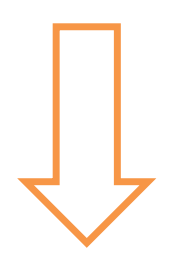

\begin{tabular}{l} 
Traditional Practice $(\mathrm{T})$ \\
Normal season: earn $=10,000$ \\
Bad season: earn $=0$ \\
No Credit Needed $(\mathrm{N})$ \\
Pay: 0 \\
\hline
\end{tabular}

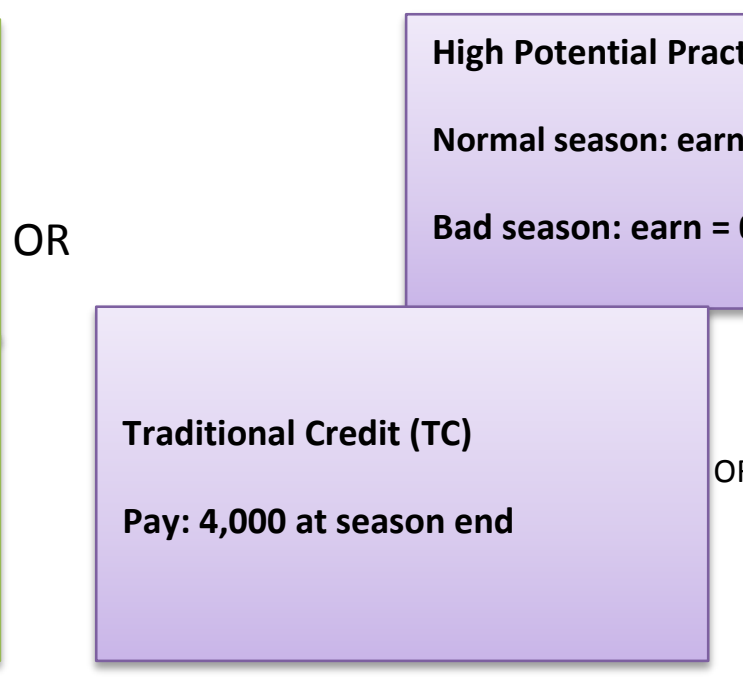

Risk Contingent Credit (RCC) Normal season: $\mathrm{Pay}=4,000$ and Premium $=200$ Bad season: Pay: 0 or Pay $=4,000$ and Premium $=200$

(2) Good season and bad season determined through random draw

(3) Basis risk determined through random draw
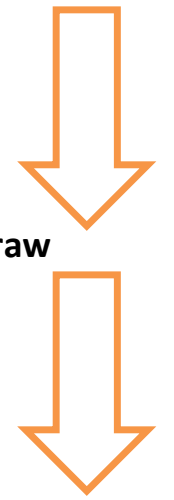

(4) End of season earning $=$ Amount earn - Loan repayment - Premium 
Table A1. Sample game responses and results

\section{RISK CONTINGENT CREDIT GAME/ ROLE PLAY}

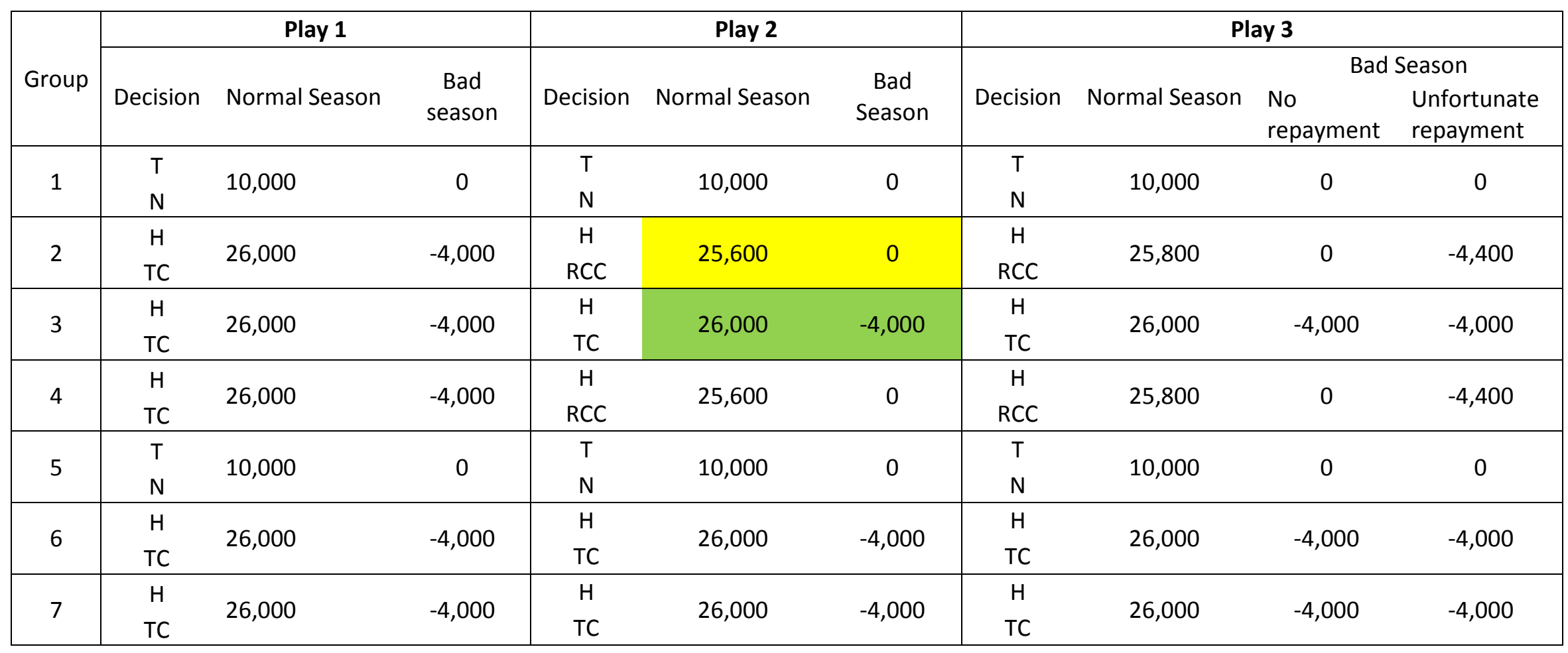

Note: $\quad[\mathrm{T}=$ Traditional Practice and $\mathrm{N}=$ No Credit $]$

$[\mathrm{H}=$ High Potential Practice and TC $=$ Traditional Credit $]$

$[\mathrm{H}=$ High Potential Practice and RCC $=$ Risk Contingent Credit $]$ 